\title{
Practicality and Performance of Daylight Trough in The Tropics: A Case Study
}

\author{
Lim Gene-Harn ${ }^{1, a}$, Gregers Reimann ${ }^{2}$,Gunaseelan Bhaskaran ${ }^{2}$,Michael Hirning ${ }^{2}$ and Morten Christensen² \\ ${ }^{1}$ Faculty of Built Environment, Universiti Malaya, 50603, Kuala Lumpur \\ ${ }^{2}$ IEN Consultants Sdn Bhd, Bangsar, 59100, Kuala Lumpur
}

\begin{abstract}
The field of office daylighting is vital for both energy efficiency practice and occupants' visual comfort. With the emergence of green building in Malaysia, building designers are exploring avenues for energy efficiency design; one common strategy is daylighting. The majority literature reviews on daylighting are skewed towards temperate or developed countries, where sky luminous condition is different from that of the Tropics. Conventional daylighting system designs redirect daylight from the envelope or atrium openings, such as light shelves. Presumed to be the pioneer daylight trough in the Tropics, this paper presents the simulated and in-situ lighting level measurements prior to occupancy. This case study presents an as-built daylight trough design which is able to daylight the office space as deep as 6 meters sufficiently. It achieves a lighting power density $1.90 \mathrm{~W} / \mathrm{m}^{2}$ and saves $39.2 \%$ of lighting energy over conventional office lighting energy. Discussed further is the practicality of working with such a system, including cost implication, return on investment and contractual challenges in reaching a consensus on the design. The results reinforce that the effectiveness of daylighting design is very dependable on the sun path and obstacles surrounding the office tower. The RADIANCE simulation correlates well to field measurement results. Further investigation into the light trough, its lighting energy savings, users' interaction, visual comfort, and glare is still ongoing.
\end{abstract}

\section{Introduction}

Daylighting proves to be one of the primary research fields in sustainable architecture design. Li \& Tsang [1] explore 35 commercial buildings built in Hong Kong from the year 1962 to the year 2004, showing there is a distinctive changing trend in fenestration system design with respect to glass type, window area, and shading devices. In the 1960's, following the emergence of artificial lighting, air conditioning, and the need for larger spaces in schools depreciated the importance of daylighting for schools in California [2]. However, the popularity of daylighting emerges along the popularity of green building rating tools across the world which emphasized indoor environmental quality and energy efficiency since the 1990s [3].

Daylight is superiority in its matching visual response of human beings, which translates into visual and nonvisual benefits [4]. Boyce et al. [5] further elaborate that lighting conditions can influence the performance of individuals via the visual system, circadian system, and the perceptual system. Yu \& Su [6] reviewed 26 papers and found that the amount of induced lighting energy savings from daylight ranges from $30 \%-87 \%$.

Conventional fenestration with the use of horizontal blinds brings the depth of daylight distribution to an average of 1.7 times the height of the window [7]. Over

\footnotetext{
a Lim Gene-Harn: limgeneharn@gmail.com
}

the last fifty years, the development of a number of reflective and refractive materials has made redirection of daylight much deep into a building possible. Mayhoub \& Carter [8] categorize two main approaches for daylighting strategies; 'beam daylighting' - adding reflective elements to conventional façade, and 'light guidance' - capturing daylight using collector devices to transport it into deep areas of the building. Focusing on the latter approach, this paper intends to compare the daylight performance of a recently installed daylight trough in Malaysia.

A brief review of light guidance systems is presented in Section 2. Section 3 describes the methodology for both via simulations and field measurements of the light trough. Section 4 then discusses the daylight performance via Daylight Factor, illumination distribution, and potential energy savings. Various design and maintenance related obstacles faced by the authors in regards to the daylight trough are discussed in Section 5. Section 6 summarizes the findings and discusses the scope of further work.

\section{2 "Light Guidance" Daylighting Strategy in the Tropics}

Ruck et al. [9] evaluate more than 30 types of daylighting systems under the International Energy Agency (IEA) 
Task 21 and proposes two groups of daylighting system, those with and without shading. The daylighting systems with shading, such as Venetian blinds and light shelves, are further divided into systems that rely primarily on the diffuse skylight and reject direct sunlight, and systems that primarily direct sunlight. The daylighting systems without shading, designed primarily to redirect daylight to areas away from the window are further categorized into another four types of systems; diffuse light guiding systems, direct light guiding systems, light scattering or diffusing systems and light transport systems. The effectiveness of a daylighting system depends on the climate, sun path, site, room design, window characteristics, artificial lighting system, and usage of the workspace [9]. The brief review in this section looks into the latter category, specifically anidolic integrated ceilings (AIC).

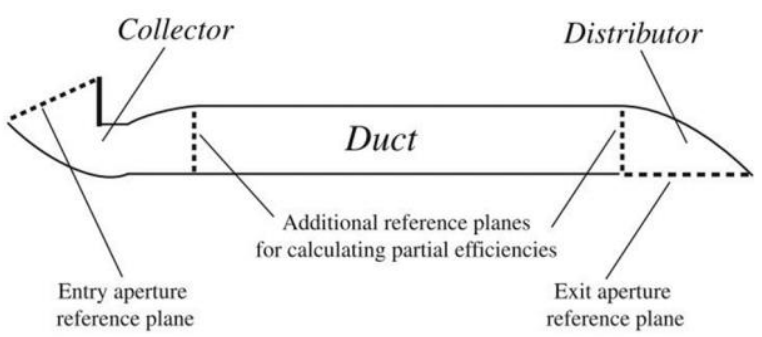

Figure 1 Components of the Anidolic Integrated Ceiling [10]

The use of AIC is unconventional in the Tropics, however, it is the system most relevant to the daylight trough be unconventional in the Tropics at the time of writing, however, most relevant to the daylight trough studied in the later section. There are limited studies on the use of AIC in the Tropics and all of them are either simulated or tested in a laboratory setting. Referring to Figure 1, AIC is designed using non-imaging optics theory and it has three major components: the collector on the external side, the rectangular mirror light duct and the distributing element at the end of the duct [10]. Wittkopf [11] tests the daylight performance of AIC under 15 different sky conditions and various sun altitudes, concluding that the daylight improvement through AIC is most significant in Singapore, compared with sky conditions in Japan's Fukuoka and United Kingdom's Sheffield. The usage of AIC in Singapore improves its illuminance ratio improvement factor (IR IF) by 3.3 and reduce glare by $14 \%$ over the simulated base case. Furthermore, AIC works best under an overcast sky with high sun altitude such as in the Tropics and distributes light across the depth of the room more evenly [11].

Three different anidolic systems (anidolic integrated ceiling, integrated anidolic system, anidolic solar blinds) are fitted to a $6.6 \mathrm{~m}$ deep room in Switzerland [12]. AIC is found to contribute 1.7 and 2.7 fold increases in the inner room (4-6 meters from fenestration) daylight factor under overcast sky conditions in a rural and urban environment respectively absent of physical obstruction. Moreover, post occupancy evaluation reaffirms that light flux is directed to the rear part of the room without glare risk and the colors are found to be more pleasant in the test room although it is physically identical to the reference room [12]. It is found that these various anidolic daylighting systems perform differently dependent upon sky condition, sun path and urban fabric.

Linhard et al. [10] evaluate the parametric factors affecting the efficiency of AIC using Photopia software under Singapore sky condition as determined by Wittkopf [11] earlier on. It is found that the coating modifications, length modification, external shading and width modification affect the efficiency of AIC by $31 \%$, $24 \%, 18 \%$ and $5 \%$ respectively. AIC efficiency is measured by the calculated exit flux of the exit aperture plane over entry flux of the entry aperture plane. Linhart \& Scartezzini [13] discovers the lowest lighting power density (LPD) in the AIC fitted office in LESO solar experimental building is less than $4.5 \mathrm{~W} / \mathrm{m}^{2}$. They then improvised the lighting distribution in regards to the interior fit out with feedbacks from 20 subjects finding that an LPD of $3.9 \mathrm{~W} / \mathrm{m}^{2}$ is feasible. Ruck et al. [9] also writes that office test room with AIC used $31 \%$ less electricity for lighting than a reference office room with 6.6 meters depth.

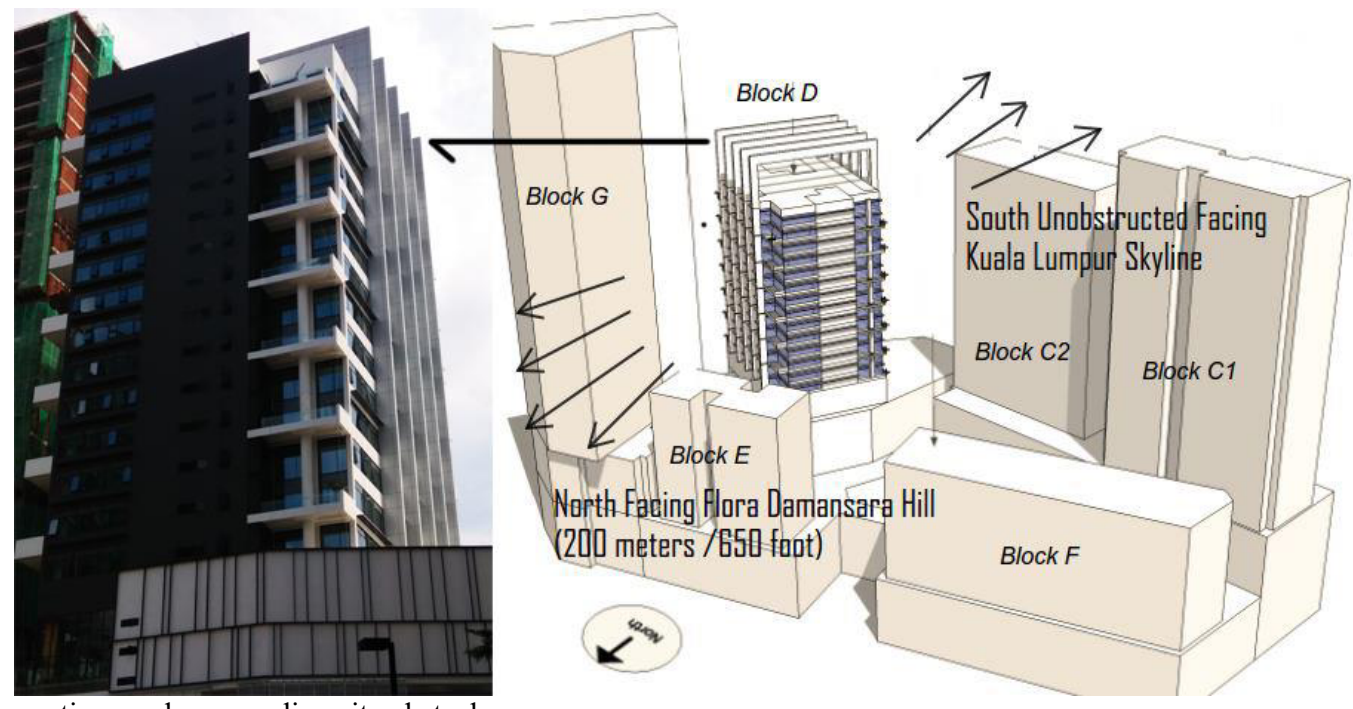

Figure 2 Perspectives and surrounding site obstacles 
Table 1 Assigned Parameters of the Material Specification

\begin{tabular}{|c|c|c|c|c|c|c|}
\hline PARAMETERS & \multicolumn{3}{|c|}{ SIMULATION SPECIFICATIONS } & \multicolumn{3}{|c|}{ As BuILT } \\
\hline Solid Surface & $\begin{array}{c}\text { Reflectance } \\
(\%)\end{array}$ & $\begin{array}{c}\text { Specularity } \\
(\%)\end{array}$ & Colour & $\begin{array}{c}\text { Reflectance } \\
(\%)\end{array}$ & $\begin{array}{c}\text { Specularity } \\
(\%)\end{array}$ & Colour \\
\hline External Wall & 80 & 0 & Metal White & 80 & 0 & Metal White \\
\hline Internal Wall & 72 & 0 & Light Gray & 72 & 0 & White Plaster \\
\hline Internal Partitions & 72 & 0 & Light Gray & 72 & 0 & Light Gray \\
\hline Floor Finish & 30 & 0 & Gray & 30 & 0 & Bare Concrete \\
\hline Ceiling Finish & 90 & 0 & White & 90 & 0 & White \\
\hline Int. Columns & 72 & 0 & White & 72 & 0 & White Plaster \\
\hline Ext. Horizontal Fins & 50 & 0 & Gray & 50 & 0 & Metal Gray \\
\hline External Vertical Fins & 50 & 30 & Gray & 50 & 30 & Metal Gray \\
\hline DT-Reflective Coat & 95 & 90 & Mirror & 95 & 90 & Alanod Mirror \\
\hline Glazing & Material & VLT & Colour & Material & VLT & Colour \\
\hline Vision Window & Glass & $42 \%$ & Clear & Glass & $42 \%$ & Clear \\
\hline DT-External Glazing & Glass & $90 \%$ & Clear & Glass & $90 \%$ & Clear \\
\hline DT-Internal Glazing & Glass & $90 \%$ & Clear & Glass & $90 \%$ & Clear \\
\hline Roller Blinds & Glass & $5 \%$ & Black & Plastic & $3-5 \%$ & Plastic Blue \\
\hline Other Conditions & \multicolumn{3}{|c|}{ Simulation Specifications } & \multicolumn{3}{|c|}{ As Built } \\
\hline Sky Condition & \multicolumn{3}{|c|}{ CIE Overcast Sky } & \multicolumn{3}{|c|}{ Afternoon Overcast Sky (Okta 3-5) } \\
\hline Surrounding Obstacle & \multicolumn{3}{|c|}{ Surrounding Office Blocks } & \multicolumn{3}{|c|}{ Surrounding Office Blocks \& Hill } \\
\hline Height of Blind & \multicolumn{3}{|c|}{$1200 \mathrm{~mm}$ from Floor Level (South only) } & \multicolumn{3}{|c|}{$1200 \mathrm{~mm}$ from Floor Level (South only) } \\
\hline Interior Fittings & \multicolumn{3}{|c|}{ No Fit Out } & \multicolumn{3}{|c|}{ No Fit Out } \\
\hline
\end{tabular}

\section{Methodology}

A similar daylight delivering strategy to AIC termed as Daylight Trough (DT), is designed and optimized for Menara Mustapha Kamal Block D located in Damansara Perdana, Malaysia (Figure 2). The 21 stories provisional GBI Gold certified office tower has an average $1,193 \mathrm{~m} 2$ of net lettable area per floor with office depth ranging from 9-16 meters and alternate level of sky gardens. The methodology to assess the performance of the DT via simulation and field measurement is described in the following sections.

\subsection{IES-VE Simulations}

The simulation software used for this study is Radiance IES [14]. The simulated model also takes into consideration adjacent building shading effects. The assigned properties barriers, reflectance, specularity and visible light transmission (VLT) are described (Table 1). The anodized reflectivity material within DT is MIR095ax4 Extra Bright from Alanod [15]. Daylight Factor (DF), defined as the ratio of indoor illuminance and outdoor illuminance is simulated under CIE overcast sky conditions [16].

\subsection{Field Measurement}

A total of 13 TENMARS TM-203 illuminance loggers were synchronized to record at 10 -second intervals concurrently. Two units were placed on the roof of the building to ensure there was no surrounding obstruction. A mirror plane was used to shade one logger against the direct sun while the other was left unobstructed (Figure 3 ). Using this setup, the readings from both loggers were compared the estimate the sky condition. If both loggers registered similar illuminance values, the sky condition was assumed to be overcast (i.e. 40k-60k lux). This data was used to determine the validity of the DF measurements. DF measurements for both North and South oriented offices separately were conducted. 11 loggers were placed at 1-meter intervals from the fenestration at a work plane height of $800 \mathrm{~mm}$. Two HOBO U-12 loggers were placed on the workplace and inside the DT respectively to monitor the ambient temperature.

Measurements were conducted on the $9^{\text {th }}$ December 2015. The winter solstice sun path causes direct sun exposure to the South oriented office. This is likely to cause a glare problem for occupants. Therefore, plastic sheets with measured VLT of 3-5\% were placed at $1200 \mathrm{~mm}$ above floor level to act as temporary blinds. However, no blinds were placed for the North oriented office as the adjacent tower and hill block any glary direct sunlight or sky view from the facades. The height of the temporary blind was also changed to $1000 \mathrm{~mm}$ above floor level which fully shut the fenestration. The illuminance contribution from DT only was obtained at the South oriented office via computing the average difference in 10 pairs of lux readings by blocking the DT exit aperture with the similar temporary blind. There was no artificial lighting in operation at the time of measurement. 


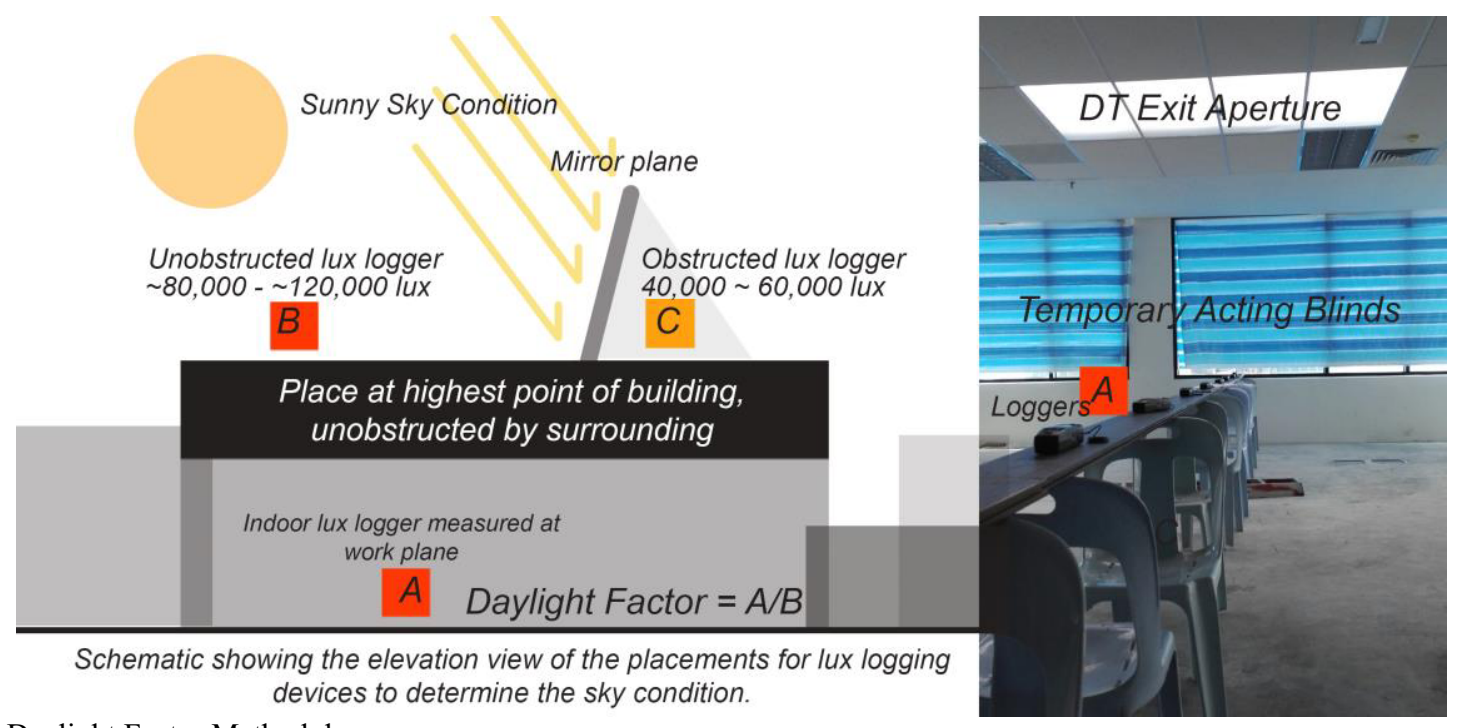

Figure 3 Daylight Factor Methodology

\section{Results - DF, Illuminance \& Energy Savings}

The measured and simulated DF for both South and North oriented offices are plotted in Figure 5 and 6. Figure 5 displays the measured and simulation DF from the DT and window glazing separately. Under the definition of useful DF (1-3.5\%) by Green Building Index [17], the result shows that the DT is capable of delivering up to 6 meters into the office space. As an alternative to DF, Wittkopf [11] proposes the usage of Illuminance Ratio Improvement Factor (IRIF), defined by the ratio of improvement of IR in design case over IR in the reference case. The IRIF for both North and South oriented offices over the reference case is summarized (Table 2). It was found that the DT has an average IRIF of 17.16 and 5.87 for 3-6 meters depth from the fenestration for the South and North oriented office respectively. The correlation between the simulated and measured results for South oriented office is high $(r=0.7577)$ while that for North oriented office is very low $(\mathrm{r}=0.0913)$. The correlation result is discussed in section 5 .

Figure 5 compares two blind configurations for the South office; blinds raised to a height of $1200 \mathrm{~mm}$ from the floor, at a VLT of $1-3 \%$, and the blinds lowered to a height of $1000 \mathrm{~mm}$ from the floor at a VLT of $10-20 \%$. Figure 6 shows the variation of illuminance distribution within the range of 200-2000lux for the first 6 meters from fenestration. It also shows that with $200 \mathrm{~mm}$ difference in blind height causes a significant increase in illuminance, at least for the first 2 meters. The recorded illuminance data was also formatted to display Useful Daylight Illuminance (UDI) stacked bar chart for easier reference [18] (Figures 8 and 9).

The expected lighting energy savings from the DT are also investigated. The calculated LPD for the office is $5.25 \mathrm{~W} / \mathrm{m}^{2}$ and $1.90 \mathrm{~W} / \mathrm{m}^{2}$ without and with the assistance of DT, both well within the MS1525:2014 maximum requirement of $10 \mathrm{~W} / \mathrm{m}^{2}$ [19]. The general lighting set point for the office is 250 lux. Using the annual hourly weather file for Kuala Lumpur, the electrical lighting savings from the daylight system by on/off controls for the lights has been calculated to be $39.2 \%$ and $13.9 \%$ for South and North oriented office respectively and $25.18 \%$ overall average. The artificial lights consist of T5 fluorescent lights which are controlled by lux sensors. There is no attempt to calculate cooling load savings, however, the measured ambient temperature differences between the light trough and work plane are $3^{\circ} \mathrm{C}$ to $4^{\circ} \mathrm{C}$ and $0.5^{\circ} \mathrm{C}$ respectively for the South (clear sky) and North oriented (overcast sky) office spaces. (Figure 4)

$$
\text { Temperature and Relative Humidity difference of office and DT }
$$

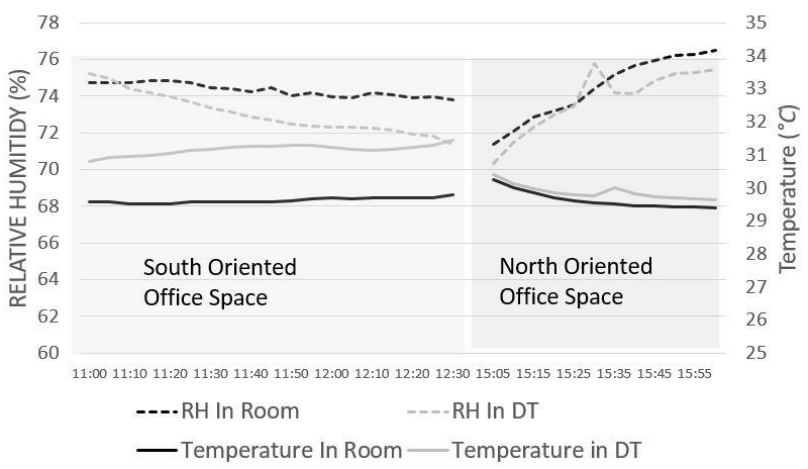

Figure 4 Ambient temperature and relative humidity differences of DT and work plane level

\section{Discussion}

\subsection{Daylight Performance}

The average IRIF of the DT from 3-6 meters depth is 17.16, as oppose to Wittkopf [11] findings on IRIF ranging from 2.0 to 3.5. Also in comparison, Scartezzini $\&$ Courret [12] finds the average DF in the rear half room is multiplied by 1.7 in the LESO building. Two of the major factors that contribute to the difference in performance may be the anidolic collector design and sky condition. The AIC with anidolic collector tested in LESO by Scartezzini \& Courret [12] is designed to 
Table 2 Comparison of simulated and measured DF and IRIF results

\begin{tabular}{|c|c|c|c|c|c|c|c|c|c|c|c|}
\hline Meters from Glass (M) & 1 & 2 & 3 & 4 & 5 & 6 & 7 & 8 & 9 & 10 & 11 \\
\hline \multicolumn{12}{|l|}{ Simulated Case } \\
\hline South Base Case & $0.50 \%$ & $0.20 \%$ & $0.15 \%$ & $0.11 \%$ & $0.08 \%$ & $0.05 \%$ & $0.03 \%$ & $0.01 \%$ & $0.00 \%$ & $0.00 \%$ & $0.00 \%$ \\
\hline North Oriented with DT & $0.30 \%$ & $0.20 \%$ & $0.90 \%$ & $1.70 \%$ & $1.20 \%$ & $0.40 \%$ & $0.20 \%$ & $0.10 \%$ & $0.03 \%$ & $0.01 \%$ & $0.00 \%$ \\
\hline South Oriented with DT & $0.50 \%$ & $0.30 \%$ & $1.00 \%$ & $1.70 \%$ & $1.30 \%$ & $0.60 \%$ & $0.40 \%$ & $0.10 \%$ & $0.05 \%$ & $0.03 \%$ & $0.01 \%$ \\
\hline \multicolumn{12}{|l|}{ Field Measurement } \\
\hline North With DT & $1.44 \%$ & $0.90 \%$ & $0.65 \%$ & $0.69 \%$ & $0.49 \%$ & $0.34 \%$ & $0.27 \%$ & $0.19 \%$ & $0.17 \%$ & $0.15 \%$ & $0.14 \%$ \\
\hline South With DT & $1.72 \%$ & $1.20 \%$ & $1.53 \%$ & $2.11 \%$ & $1.49 \%$ & $1.03 \%$ & $0.70 \%$ & $0.40 \%$ & $0.34 \%$ & $0.21 \%$ & $0.20 \%$ \\
\hline \multicolumn{12}{|c|}{ Illuminance Ratio Improvement Factor IRIF (Measured) } \\
\hline North Oriented & 2.88 & 4.50 & 4.34 & 6.31 & 6.08 & 6.77 & 9.13 & 18.76 & 0.17 & 0.15 & 0.14 \\
\hline South Oriented & 3.44 & 6.00 & 10.20 & 19.19 & 18.60 & 20.61 & 23.50 & 39.65 & 0.34 & 0.21 & 0.20 \\
\hline
\end{tabular}

achieve a high angular selectivity that collects diffuse light from the upper half hemisphere. The measured DT with a deep overhang is intended to shade it from afternoon sun's direct light, which has the lowest altitude of 65 degrees. Unlike LESO's AIC, the DT collects only diffuse light, which comes primarily from the hemisphere. The difference in physical details such as the opening aperture exiting aperture ratio and height of duct are significant, but not described. The relatively high DF near perimeter found by Scartezzini \& Courret [12] indicates that no blinds in used, which is not the representative case for Tropics. Chaiwiwatworakul \& Chirarattananon [20] measured the luminous efficacy of various sky conditions in Bangkok and finds that variation of efficacies is influenced by the sky conditions and sun positions. With the higher solar insolation and higher latitude sun path, and also as simulated by Wiitkopf [11], the DT is proven to be more efficient in the Tropics. The South oriented office shows a significant improvement in illuminance in the first 6 meters from the façade (primarily the span below the exit aperture of DT). However, the North oriented office shows only little improvement as it faces a major tower building and hill. In accordance to the Malaysia Standards MS1525:2014 and the Green Building Index NonResidential New Construction tool (NRNC), the lighting illumination requirement for office space is 300400 lux or $1-3.5 \%$ DF $[17,19]$. These standards apply only for artificial lights as various reviews have affirmed that subjects accept daylight illuminance ranging 2002000 lux $[4,18,21]$. This corresponds well to the DF of $0.5-3.5 \%$ instead of $1-3.5 \%$, as an external illuminance under overcast sky ranges $30 \mathrm{k}$ lux to 50k lux [7].

The lighting energy savings do not entirely depend on the coverage of the DT but the lighting control system and positioning of artificial lighting as well [13]. It can be expected that only the two nearest rows of artificial lighting to the perimeter will be assisted by the DT. As elaborated by Linhart \& Scartezzini [13], the positioning of office interior and task area matter as much in ensuring appropriate illuminance level in right places. Also, individuals lighting expectation is influenced by previous office experience so there should be localized form of lighting control such as energy efficient and ergonomic task light $[4,13,22]$.

\subsection{Radiance \& Daylight Factor}

The correlation between simulated and measured DF proves the reliability of radiance program in simulating the effectiveness of the DT daylighting strategy. However as shown in the North oriented office, the simulated contribution from DT via radiance does not show the significant shading impact from the adjacent building when compared to the measured result. The discrepancy indicates the possibility of IES-VE not registering the adjacent buildings blocking the daylight which needs to be further investigated. The measured DF is found to be constantly higher than what radiance simulated, this may be due to the unrealistic CIE Overcast Sky which does not represent the actual dynamic sky condition as argued by many reviews $[6,16,18,21,23]$

\subsection{Payback Period}

The total additional cost of the DT per meter square office area (Nett Lettable Area) is RM38.21/ $\mathrm{m}^{2}$ $\left(\$ 8.70 / \mathrm{m}^{2}\right)$ which includes the additional reflective aluminum sheet from Alanold and Gypsum Board. The operational energy savings computes the avoided lighting energy usage with the medium commercial tariff rate $(\mathrm{C} 1)$ at the price of $\mathrm{RM} 0.365$ (\$8cents) from the national electricity provider TNB. Lamp replacement cost annually is reduced due to the increased lifespan of T5 lights. This assumes RM40 for the cost per lamp and RM7 for labor charges. The expected payback period for the DT is 20.4 years.

However, as noted by Mayhoub \& Carter [8], the conventional payback period does not capture intangible items such as building cooling savings, carbon tax savings, residual value, enhanced corporate prestige, and most importantly, the effect of daylight on human performance. A study from Carnegie Mellon University (CMU) shows that costs of an employee 160 times that of energy. Conventional daylight from windows yielded energy savings of $£ 7 / \mathrm{m}^{2}$ and annual productivity gains of $£ 142 / \mathrm{m}^{2}$ [8]. 


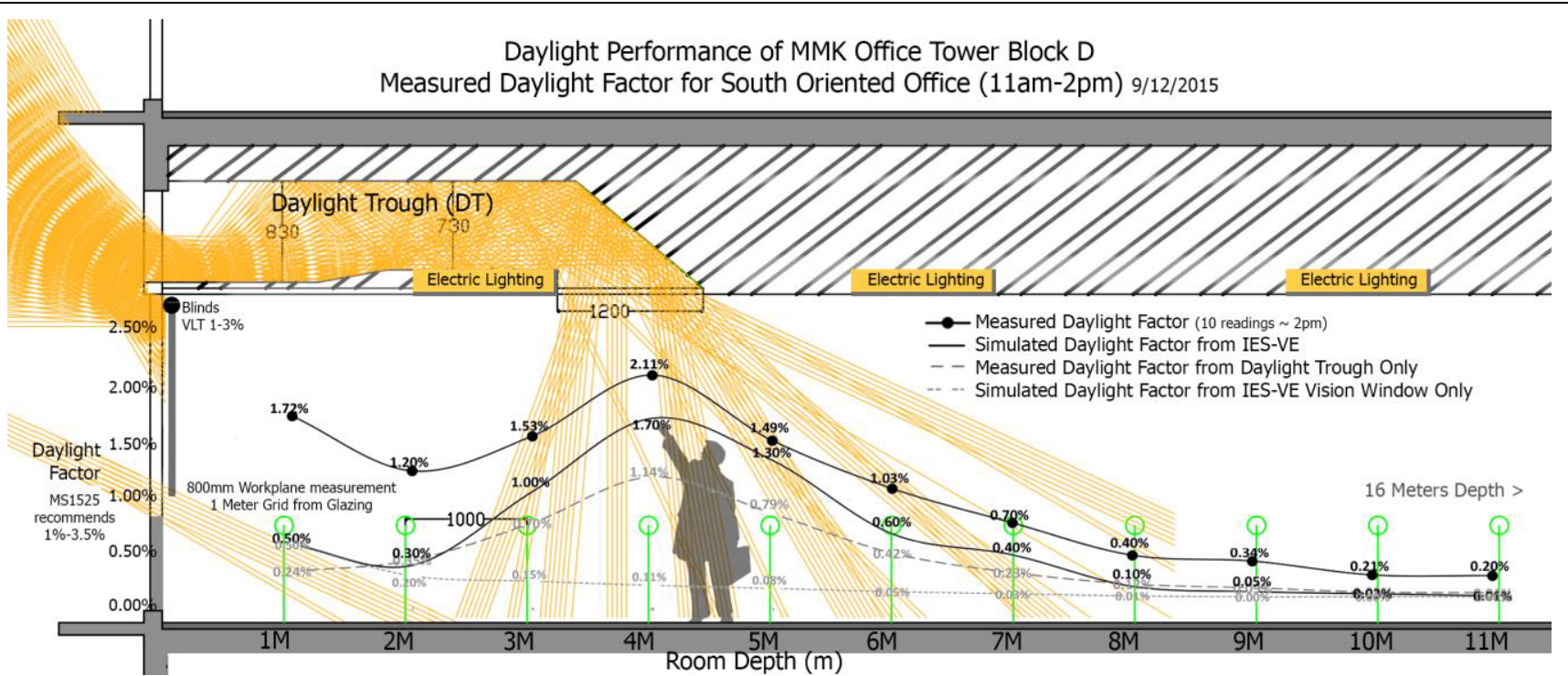

Figure 5 Cross section of DT and interpolated measured DF values for South oriented office

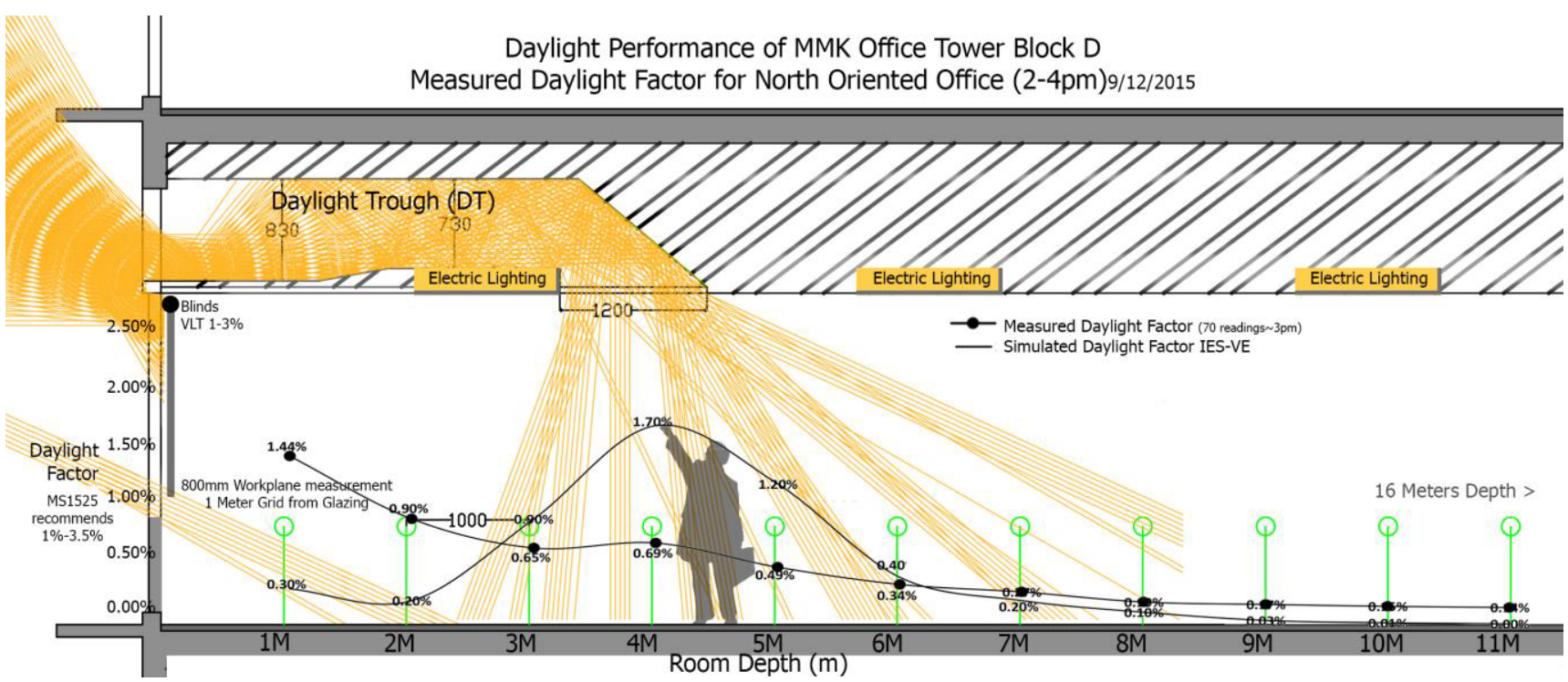

Figure 6 Cross section of DT and interpolated measured DF values for North oriented office. Both measured and simulated results do not include the usage of blinds.

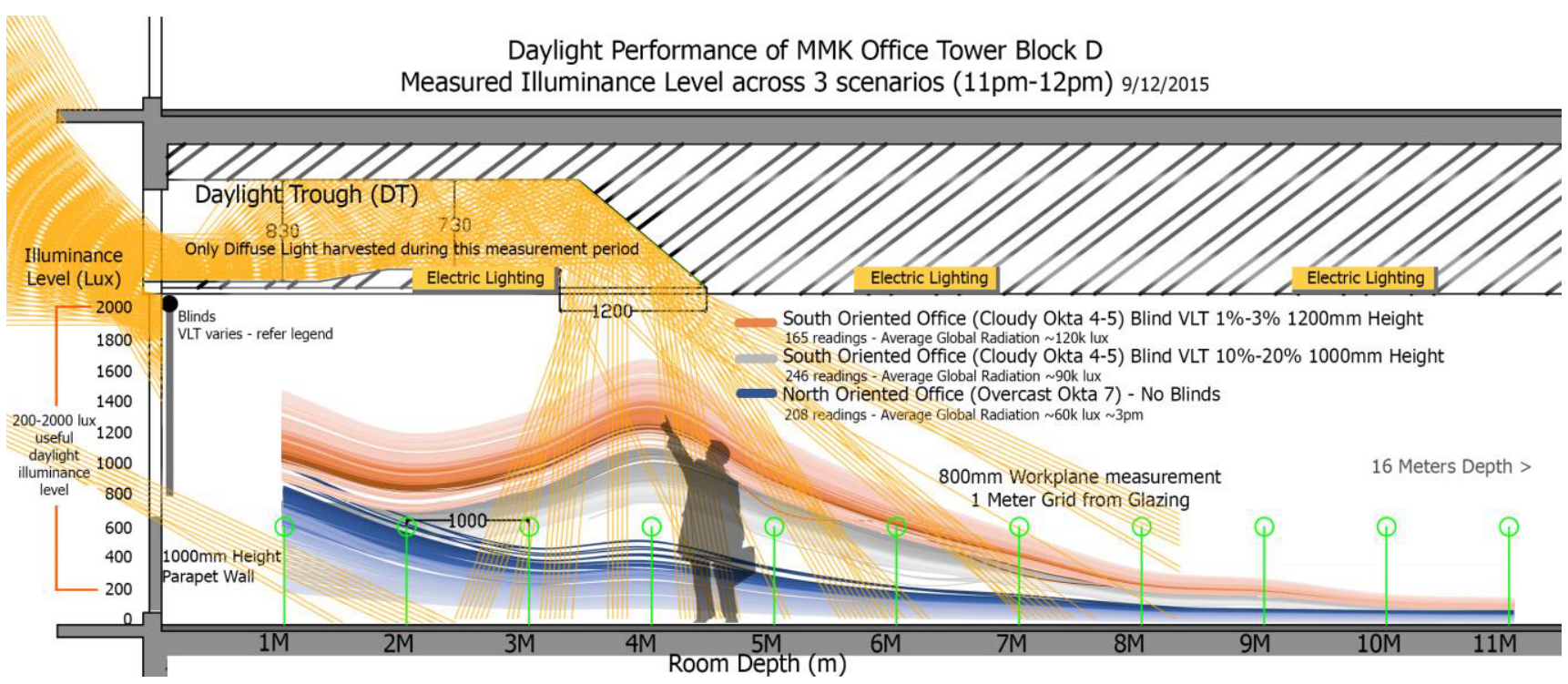

Figure 7 Continuous measured illuminance level for South and North oriented office 


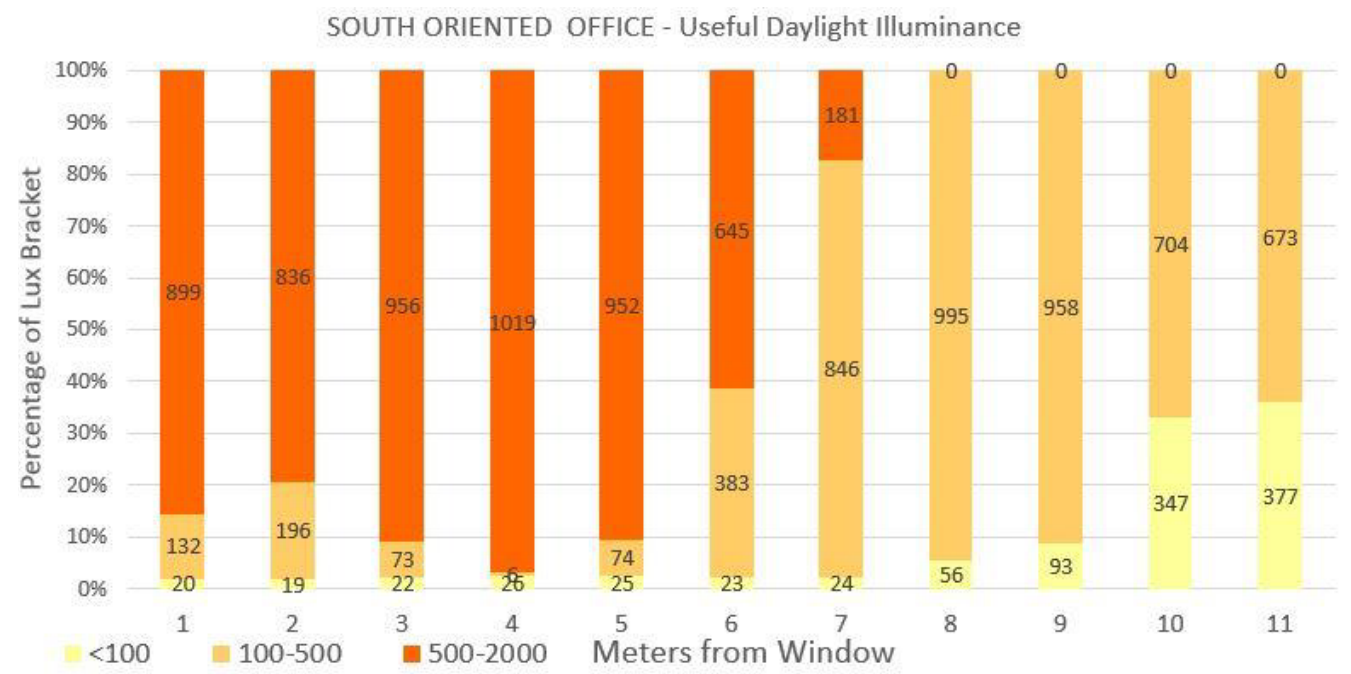

Figure 8 UDI distribution for South oriented office over the period of a day

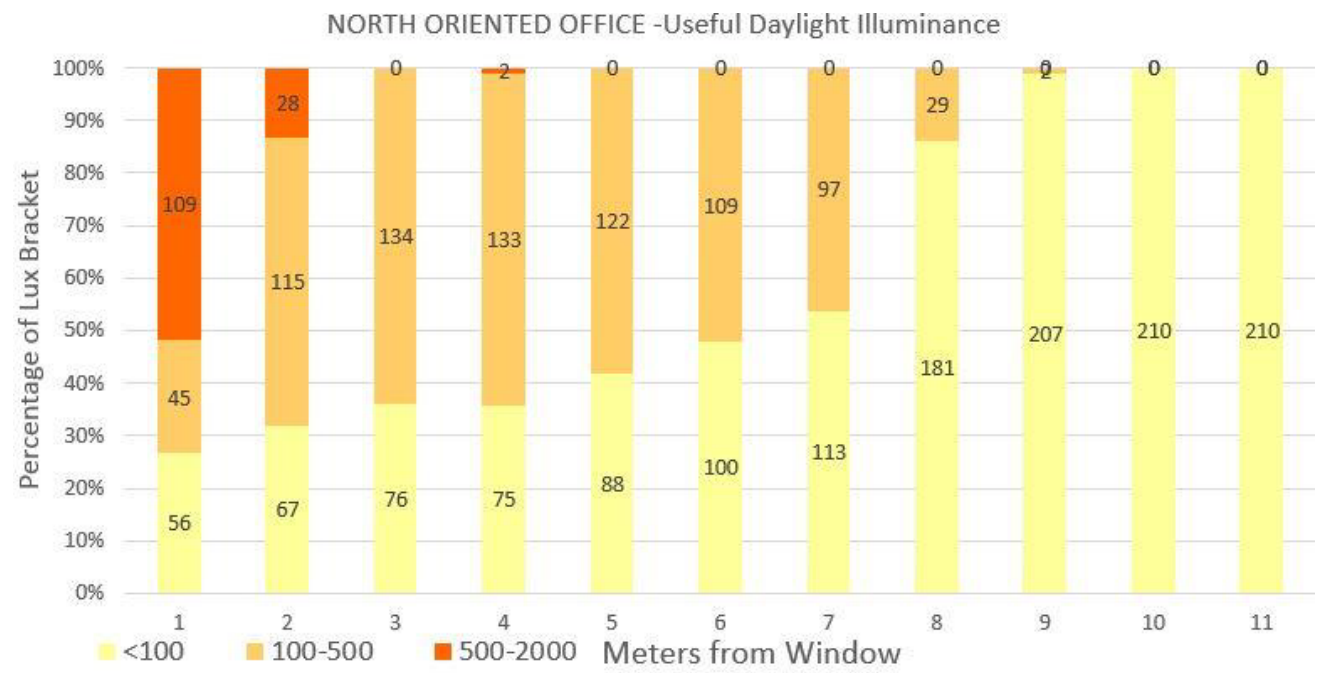

Figure 9 UDI distribution for North oriented office over the period of a day

The study also concludes that by factoring in all the mentioned intangible benefits, the usage of tubular daylight guidance systems in London has a payback period of 6 years. This could potentially be even faster in the Tropics due to higher annual sky luminance.

There are three factors affecting payback periods: electricity prices, system capital cost, and available external local illuminance [8]. In view of the increasing commercial electricity tariffs in Malaysia and other advantages as mentioned, the payback period for the DT is likely much lower. However, this paper is unable to quantify the whole life cycle costing (WLCC) as suggested by Mayhoub \& Carter [8] as there is a lack of localized literature on the intangible benefits.

\subsection{Contractual \& Maintenance Practicality Experience}

The design of the DT has to cater to three objectives; constructability considering all other mechanical and electrical components in the ceiling space, maintenance of the DT, and daylight performance. The design of the DT does not span across entire ceiling space as there are pockets of ceiling space for fresh air ducts and fire sprinklers (Figure 10). The DT design only caters for the center of the office space as the corners with shallow depth should get sufficient daylight from fenestration alone. The initial DT design had the upper light trough tilted to allow redirection of daylight deeper into space, however this was later revised due to constructability considerations (Figure 12).

The evolution of the design also considered maintenance which suggested using robot vacuum cleaners every half year to clean the DT. As there was an uncertainty over the robot's navigation due to height clearance and frequent ceiling hangers, and even leveling, the act of "over-engineering" also potentially added cost. Also, the unconventional issue of additional lateral load and movements by the robot vacuum concerns the warranty of ceiling panel suppliers and various sub-contractors. With the complication of liability and potential defects, the DT was redesigned to be isolated and enclosed which accumulates only minimal dust. Telescopic mops will be used via the translucent exit aperture of the system to maintain the DT. Figure 11 shows the axonometric exploded view to illustrate the arrangement of systems at ceiling level. 


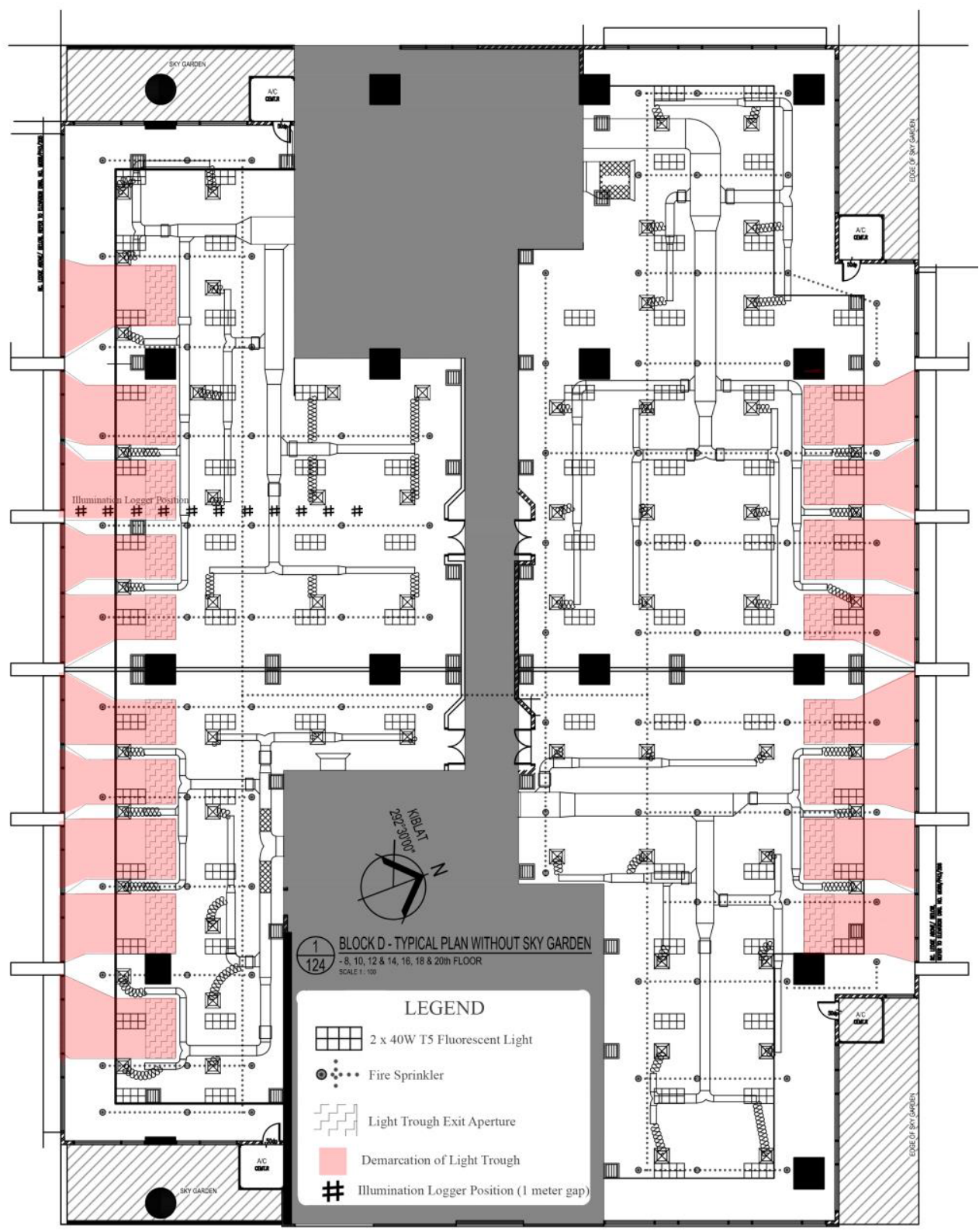

Figure 10 Ceiling layout plan of a typical office level with DT location demarcated

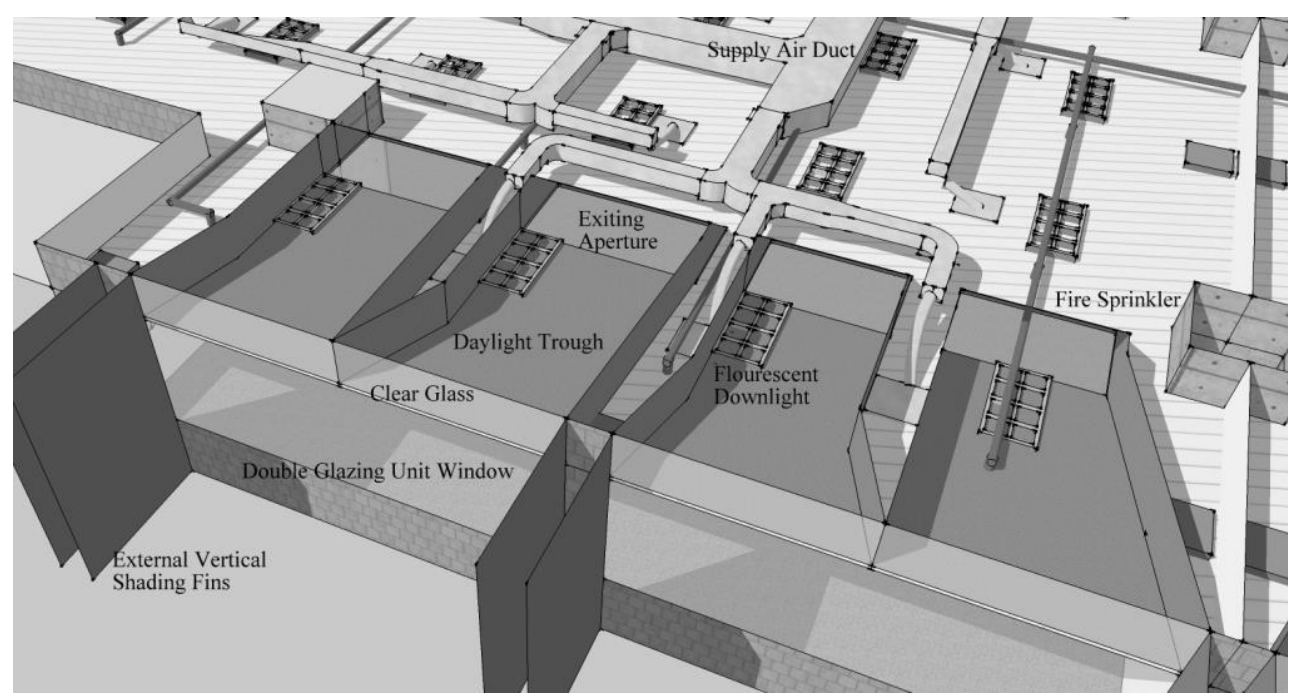

Figure 11 Illustrated axonometric exposed view of the ceiling components arrangement 


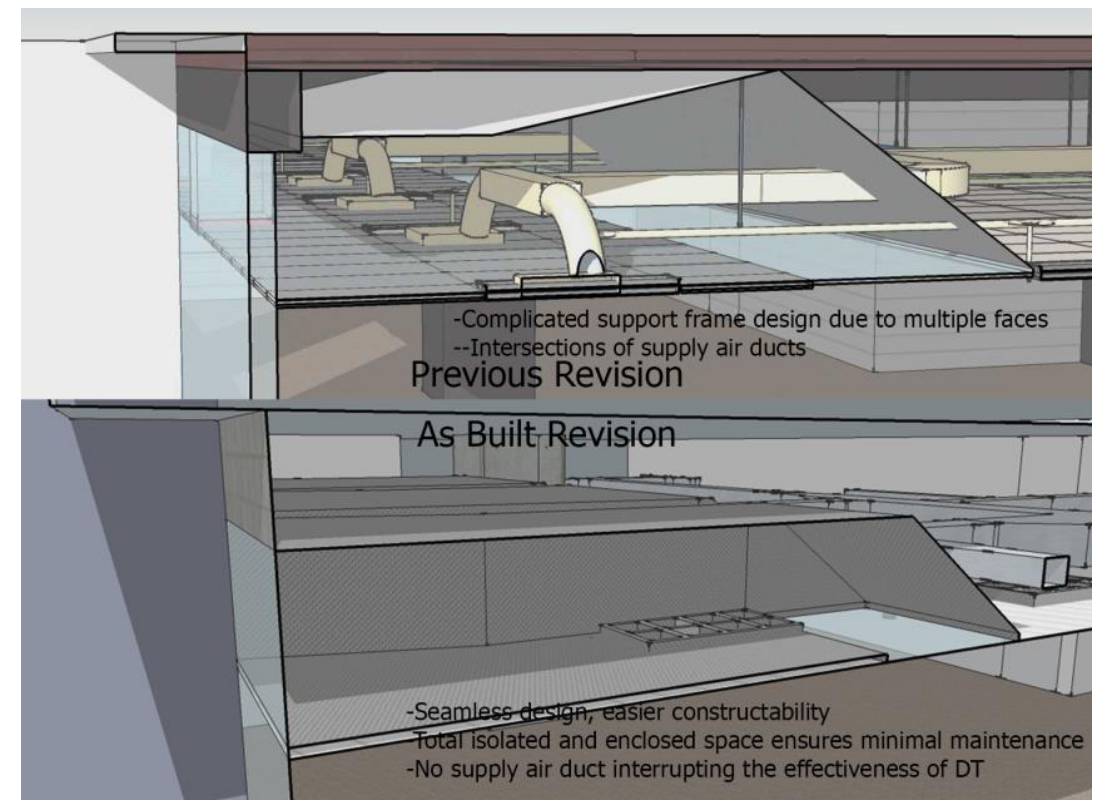

Figure 12 Illustration of revisions of DT

\section{Conclusion \& Recommendation}

This case study summarizes the effectiveness and practicality of a novel daylight trough in Damansara Perdana, Malaysia. The correlated simulation and field measurement results demonstrate that reliability of Radiance in IES-VE can be used to study such an innovative daylighting system in advance. Unlike most previous simulated or experimental mock-up based research papers, this paper shares the experience of practical on-site constructability and maintenance of DT in the Tropics.

The DT has the potential to bring in effective daylight (DF 1-3.5\%) to a depth of 6 meters from the fenestration. The IRIF of the DT varies from 4.34 and 20.61 for 3 to 6 meters depth from fenestration. Radiance simulation result in IES-VE correlates well with the field measurement $(r=0.7577)$ however precaution has to be taken for adjacent building shading effects. The design of DT needs to take account of the surrounding obstacles and orientation for its daylight performance, as shown by the significant difference in IRIF of the South oriented office which is unobstructed and north oriented office obstructed by tower and hills.

The incremental cost for DT is RM $38.21 / \mathrm{m}^{2}$ $\left(\$ 8.70 / \mathrm{m}^{2}\right)$ and it is estimated to save as much as $39.19 \%$ of artificial lighting energy annually. The payback period of the DT is 20.4 years with the consideration of operational and maintenance savings. However as elaborated, the whole life cycle cost shall include many intangible aspects such as carbon mitigation and office productivity which was out of the scope of this investigation. The constructability and maintenance of DT have to be accounted for, together with the designs of many other mechanical and electrical components in the ceiling space such as supply air duct, fire sprinkler, and artificial lights. The difference in ambient temperature of DT and office work plane level is $3^{\circ} \mathrm{C}$ to $4{ }^{\circ} \mathrm{C}$ and $0.5^{\circ} \mathrm{C}$ during clear and overcast skies, respectively. The lighting power density of the office space is $5.25 \mathrm{~W} / \mathrm{m}^{2}$ and $1.90 \mathrm{~W} / \mathrm{m}^{2}$, with and without the assistance of DT, respectively.

Recommendation. The effectiveness of the DT should be further investigated by post occupancy visual comfort survey as this investigation only investigates merely on daylight illuminance performance without fit out. Aside from glare analysis and artificial light interaction studies, a similar illuminance measurements should be done for the summer solstice and equinox. This will give a fair picture of the effectiveness of the DT throughout the year.

\section{References}

[1] D. H. W. Li and E. K. W. Tsang, "An analysis of daylighting performance for office buildings in Hong Kong," Build. Environ., vol. 43, no. 9, pp. 1446-1458, (2008)

[2] L. Heschong and F. Oaks, "Windows and Classrooms: A Study of Student Performance and the Indoor Environment," 2003.

[3] Z. A. Hamid, A. F. Roslan, M. C. Ali, F. C. Hung, M. S. M. Noor, and N. M. Kilau, "Towards a national green building rating system for Malaysia," Malaysian Constr. Res. J., vol. 14, no. October, pp. 0-16, (2014)

[4] A. D. Galasiu and J. a. Veitch, "Occupant preferences and satisfaction with the luminous environment and control systems in daylit offices: a literature review," Energy Build., vol. 38, pp. 728-742, (2006)

[5] P. R. Boyce, C. Hunter, and O. Howlett, "The Benefits of Daylight through Windows," 2003.

[6] X. Yu and Y. Su, "Daylight availability assessment and its potential energy saving estimation -A literature review," Renew. Sustain. 
Energy Rev., vol. 52, pp. 494-503, (2015)

[7] CK Tang and N. Chin, Building Energy Efficiency Technical Guideline For Passive Design. Building Sector Energy Efficiency Project BSEEP, 2013.

[8] M. S. Mayhoub and D. J. Carter, "The costs and benefits of using daylight guidance to light office buildings," Build. Environ., vol. 46, pp. 698-710, (2011)

[9] N. Ruck, S. Aydinli, J. Christoffersen, Gi. Courret, I. Edmonds, R. Jakobiak, M.

Kischkoweit-Lopin, M. Klinger, E. Lee, and L. Michel, Daylight in Buildings: A source book on Daylighting systems and components. Lawrence Berkeley National Laboratory, 2000.

[10] F. Linhart, S. K. Wittkopf, and J. L. Scartezzini, "Performance of Anidolic Daylighting Systems in tropical climates - Parametric studies for identification of main influencing factors," Sol. Energy, vol. 84, no. 7, pp. 1085-1094, (2010)

[11] S. K. Wittkopf, "Daylight performance of anidolic ceiling under different sky conditions," Sol. Energy, vol. 81, no. 2, pp. 151-161, 2007.

[12] J. L. Scartezzini and G. Courret, "Anidolic daylighting systems," Sol. Energy, vol. 73, no. 2, pp. 123-135, (2002)

[13] F. Linhart and J. L. Scartezzini, "Minimizing lighting power density in office rooms equipped with Anidolic Daylighting Systems," Sol. Energy, vol. 84, no. 4, pp. 587-595, (2010)

[14] Integrated Environmental Solutions, "Radiance View User Guide," 2015. [Online]. Available: http://www.iesve.com/downloads/help/ve2012/Li ghting/Radiance.pdf. [Accessed: 01-Jan-2006].

[15] Alanod-xxentria, "MIRO95ax4 Data Sheet," Alanod-xxentria, 2014. [Online]. Available: http://www.alanodxxentria.com/download/technical/201405060428 23817.pdf. [Accessed: 01-Jan-2016].

[16] K. Kensek and J. Suk, "Daylight Factor (overcast sky) versus Daylight Availability (clear sky) in Computer-based Daylighting Simulations," J. Creat. Sustain. Archit. Built ..., vol. 1, pp. 3-14, (2011)

[17] Green Building Index, "GBI NRNC Non Residential New Construction Design Tool." Green Building Index, p. 76, 2011.

[18] A. Nabil and J. Mardaljevic, "Useful daylight illuminance: a new paradigm for assessing daylight in buildings," Light. Res. Technol., vol. 37, no. 1, pp. 41-59, (2005)

[19] Departments of Standards Malaysia, MS1525 2014 Code of Practice on Energy Efficiency and Use of Renewable Energy for Non Residential Buildings (2nd Revision). 2014.

[20] P. Chaiwiwatworakul and S. Chirarattananon, "Luminous efficacies of global and diffuse horizontal irradiances in a tropical region," Renew. Energy, vol. 53, no. 0, pp. 148-158, (2013)

[21] M. S. Alrubaih, M. F. M. Zain, M. a. Alghoul, N. L. N. Ibrahim, M. a. Shameri, and O. Elayeb,
"Research and development on aspects of daylighting fundamentals," Renew. Sustain. Energy Rev., vol. 21, pp. 494-505, (2013)

[22] Heschong Mahone Group, "High Efficiency Office: Low Ambient/Task Lighting Pilot Project," 2009.

[23] F. Maamari and M. Fontoynont, "Analytical tests for investigating the accuracy of lighting programs," Light. Res. Technol., vol. 35, no. 3, pp. 225-242, (2003) 